\title{
Attributes of entrepreneurs at an arts festival
}

\author{
M. Saayman, M. Douglas and †S. de Klerk \\ Institute for Tourism and Leisure Studies \\ and \\ †School of Business Management \\ Thinkwell Research Unit. \\ North-West University (Potchefstroom Campus) \\ Potchefstroom \\ *Melville.Saayman@nwu.ac.za
}

\begin{abstract}
The purpose of this article is to determine the attributes of entrepreneurs at festivals, in this case an arts festival. The reason for choosing an arts festival is that the largest festivals (judged by number of visitors and income generated) hosted in South Africa annually are arts festivals. A literature review revealed that this type of study had not previously been conducted in South Africa. In order to generate proper data, a survey was conducted of all small businesses that were trading at one of South Africa's largest arts festivals, namely the Aardklop National Arts Festival, held annually in the city of Potchefstroom. 222 useable questionnaires were captured and the data analysis included a factor analysis and descriptive results. The main results reveal that the most important attributes are a need for achievement, being successful, having the necessary organising skills, selfedification, being explorative, and commitment.
\end{abstract}

Key words: entrepreneurs, arts festivals, event tourism, South Africa, attributes, Aardklop National Arts Festival

\section{Introduction}

The three largest arts festivals in South Africa are the Grahamstown Festival, held in the town of Grahamstown, the Aardklop Festival in Potchefstroom and the Klein Karoo National Arts Festival in Oudtshoorn (Saayman \& Saayman, 2006:570-571). The Aardklop National Arts Festival has been held annually since 1997 in the town of Potchefstroom, in the North West province of South Africa. This cultural festival incorporates theatre, dance, music, cabaret and visual arts that are held in a variety of venues in and around the town. A large craft market and open-air performances also form part of the event, drawing crowds of more than 50000 people every year, as well as more than 200 entrepreneurs, all selling their arts, crafts and other goods and services (National Arts Festival, 2007).

Festivals and events play an important role in tourism, as indicated by McKercher, Mei \& Tse (2006:56-57), Trigg (1995:136) and Anwar \& Sohail (2004:161-162), since they offer entertainment and serve as attractions to tourists and visitors alike. Festivals and events are also used to boost tourism; tourists and visitors spend large amounts at festivals on a wide variety of products and services such as accommodation, restaurants, shows, curios and transport (Van der Merwe, 2008:66-67). Festivals and events are also seen as a tool for addressing seasonal fluctuations. Van der Merwe (2008:15-16) also mentions that one of the benefits of festivals and events, and therefore tourism, is to promote entrepreneurial opportunities. Aitchison and Pritchard (2007:9) point out that arts festivals, as incomegenerating events, can be seen as an entrepreneurial opportunity to maximise economic 
activity, attract and retain visitors and contribute to forming cultural identity at the festival. Spilling (1996:92-94) and Tyson, Hayle, Truly, Jordan \& Thame (2005:324) concur that events, especially big events, can serve as a trigger for entrepreneurial activities.

According to Dahles and Bras (1999:2), little attention has been given to the economic potential of tourism, which includes events and festivals, and the role of entrepreneurial activity. This is despite the fact that entrepreneurship is globally recognised to be a solution to unemployment problems, with the growth in terms of people being employed by small businesses being larger than the contribution of small businesses to the GDP of the country (Elliot \& Boshoff, 2007:15). In general, more than 80 percent of all new job opportunities are created in new and upcoming small and medium businesses (Kroon, 2002:215). The latter adds that authorities worldwide boost entrepreneurship not only because of its ability to create jobs, but also because entrepreneurship brings economic development and growth to a country and is seen as the most powerful force to establish economic and social mobility. In 2005 the then president of South Africa, Mr Thabo Mbeki, announced that all regulations applicable to small businesses in South Africa should be reviewed, in order to find ways in which Small, Micro and Medium Enterprise (SMME) business development could be supported and enhanced (Starting your own business, 2005:3). In view of the influence of small businesses in particular on the economic growth of a country, and the significant role of the tourism sector on small business development, tourism has the potential to contribute to the development of the South African economy in a visible way (Elliot \& Boschoff, 2007:16).

Longenecker, Moore and Petty (2003:19) state that without entrepreneurs there would be far less development and innovation. Entrepreneurs serve as founders, coordinators and finishers (Brush, 2008:23). A better understanding of the entrepreneurs' contribution to arts festivals will enable festival organisers to get a better understanding of the role and function of entrepreneurs at these festivals.

\section{Literature review}

The part played by entrepreneurship in production was first recognised in 1890, when the factors of production were stipulated as land, capital and organisation (Marshall, 1920). In 1912, a more direct reference to entrepreneurship appeared in Schumpeter's work Theorie der Wirtschaftlichen Entwicklung (Schumpeter, 1912; 1942). Organisation is the coordinating factor that brings the other factors together, and it is believed that entrepreneurship is the driving element behind organisation (Marshall, 1920). Entrepreneurs can create new commodities or improve the plan of producing an old commodity through creative organising (Olivier, 2002:17).

Thus it is accepted that entrepreneurship is of significant importance and essential for the economic development of every country, because through entrepreneurship new ideas and inventions are developed and this enables continual improvement of societies and their organisations (Kimani, 2004:10). According to Timmons and Spinelli (2004:3), the world's economic and social structures have been transformed by a new generation of entrepreneurs, leading to a heritable entrepreneurial code. America has, since its founding in 1776, given a free rein to entrepreneurs, resulting in ground-breaking entrepreneurship during the past 300 years (Timmons \& Spinelli, 2004:3). 
Currently there are many institutions and organisations focusing on educating people to becoming successful entrepreneurs. Gordon Brown, the then Chancellor of NFTE (Network For Teaching Entrepreneurship), announced on November 15, 2005, that in one week alone, Britain hosts approximately 2000 business events for hundreds and thousands of young people, which is proof of the importance of entrepreneurship in the UK (Brown, 2005:1). People exposed to entrepreneurship frequently express more ability to exercise creative freedom, higher self-esteem, and an overall greater sense of control. A robust entrepreneurial culture will maximise individual and collective economic and social success on a local, national and global scale (Start you own business, 2005:3). Entrepreneurs contribute to innovation, which in turn contributes to the profitability and growth of the organisation or business, and therefore the economy (Muhanna, 2006:64). Determining market needs and introducing new organisations, the free-enterprise economic system of this millennium is formed by entrepreneurs as decision makers (Longenecker et al., 2000:3).

South Africa in itself has a large number of unemployed people, especially among historically disadvantaged individuals. During 1996, the National Small Business Act of 1996 (Act 102 of 1996) as amended, was developed to attempt to address policy gaps in terms of unemployment and poverty amongst, in particular, previously disadvantaged individuals. Adding to the need for such an act is the fact that South Africa has shown an average 3\% economic growth since the political change in the mid-1990s and the country has also experienced even higher growth rates over the past five years (Africa Policy Information Centre, 2002). This has resulted in a growing interest in entrepreneurship (Haasje, 2006:43). National government policy and planning in South Africa has adopted the development of Small, Micro and Medium Enterprises (SMMEs) as a continuous theme linked to the objectives of economic transformation. The challenge, however, lies in the fact that the country has an extremely diverse group of businesses, all of which need different kinds of support interventions (Rogerson, 2005:623).

In several investigations, tourism has been identified as being potentially one of the key economic drivers in South Africa (Rogerson, 2005:623). According to Saayman and Olivier (2005:134), tourism plays a vital role to the development of South Africa and its people, employing an estimated 600000 people. It is evident in the support of particular groups of tourism, including events and festivals.

Ndabeni and Rogerson (2005:130) state that entrepreneurship in tourism has attracted limited research. Furthermore, within the literature of tourism there exists a critical debate on the role of tourism in small business and its relation to rural communities' economic development (Ndabeni \& Rogerson, 2005:130). However, Binns and Nel (2002:235-237) state that in recent years, festivals and special events have become one of the fastest growing types of tourist attraction (festivals increase at a rate of about 200 annually in South Africa), and the number of conceptual and empirical studies on festivals and special events has increased. One of the reasons why festivals are important from an entrepreneurial point of view is that they generate large amounts of funds: for example, the Klein Karoo National Arts Festival (KKNK) generates over R60 million, and the Grahamstown and Aardklop National Arts Festivals over R50 million each (Slabbert, Saayman, Saayman \& Kruger, 2008a;27; Slabbert, Viviers, Saayman \& Saayman, 2008b:47; Kruger, Saayman \& Saayman, 2008:29). According to Saayman \& Saayman, (2006:571) and Spilling (1996:92-94), not enough research has been done concerning entrepreneurship at festivals or events, and the absence of international case studies supports this notion. 
The following studies focus on entrepreneurship in tourism mainly by concentrating on factors such as barriers and constraints, skills development, rural tourism, opportunities, entrepreneurial culture and entry level requirements. The lack of market access is also known to be cited as a major concern for entrepreneurs, especially for SMME businesses. None of these studies indicated the attributes of the entrepreneur specifically at arts festivals. The literature review did, however, reveal the following research: Cleverdon (2002), Van der Westhuizen (2003) and Olivier (2002) conducted investigations on the barriers and constraint factors that influence entrepreneurs in the tourism industry. Kirsten and Rogerson (2002) studied business linkages and the entrepreneur. Spilling (1996) developed a framework for entrepreneurs at events and specifically the Olympic Games. Barnard (1988) identified skills for small tourism businesses in the Pretoria-Witwatersrand-Vereeniging area. Mitton (1998) also focused on the skills that entrepreneurs require and how tertiary training can alleviate this gap. Ndabeni and Rogerson (2005) and Austin (2003) investigated the possibilities for entrepreneurial development in rural tourism. Olivier (2002) did a comprehensive analysis of opportunities for small, medium and micro-tourism businesses in South Africa.

The literature review did, however, reveal research concerning the profiles, characteristics and contributions of entrepreneurs in general. These studies, listed below, lead the authors to the understanding that no common description exists for the general attributes of entrepreneurs. However, the literature review did indicate some attributes from different studies. They include Rotefoss and Kolvereid (2005:110-112), who place an emphasis on entrepreneurs' willingness to take calculated risks, as well as making use of market opportunities. Saayman \& Snyman (2005:3) state that entrepreneurs are synonymous with innovation and that their actions are profit driven. These researchers add that successful entrepreneurs have strong management skills supported by the following characteristics: ambition, dedication, creativity, initiative, innovation, positive state of mind and vision (Saayman \& Snyman, 2005:12-16). Hormozi (2004:279) has found that although entrepreneurs are profit driven, their desire to achieve lies in their orientation towards excellence. Hormozi (2004:279) adds that entrepreneurs are optimistic individuals who are prepared to work hard in order to be rewarded in financial and psychological ways.

The evolution of entrepreneurship throughout the decades has led to entrepreneurs becoming a force to be reckoned with as members of the business community (Hormozi, 2004:278). Festivals can be seen as an unexplored market that extends the market reach of SMME businesses in the tourism sector to a more extensive geographical reach and therefore more customers (Elliot \& Boshoff, 2007:15).

Based on the above, the purpose of this research is to determine the attributes of entrepreneurs at the Aardklop National Arts Festival.

\section{Method of research}

Data used in the analysis were gathered during the Aardklop National Arts Festival, held on 22-29 September 2007, using an entrepreneurial-based questionnaire. The methodology used will be discussed under the following headings: the questionnaire; the samples; and the method. 


\section{The Questionnaire}

The questionnaire used to survey entrepreneurs at the Aardklop National Arts Festival is based on the work of Barnard (1988:169), Mitton (1998:113), Olivier (2002:151) and Van der Merwe (1994:352). The questionnaire was personally distributed to local businesses and entrepreneurs during the Aardklop Festival. The basic layout of the questionnaire consisted of three sections. Section A focused on the demographical information, while Section B was concerned with information on the businesses. Section C primarily focused on festival information. The questionnaire consisted of open and close ended questions as proposed by Tustin, Lighthelm, Martins \& Van Wyk. (2005). A psychometric response scale (Likert scale 1-5) was used to specify the level of agreement to the 28 listed statements. These questions were used to generate as much information as possible regarding the entrepreneur, business background, risks involved as well as the contributions entrepreneurs make towards the Aardklop National Arts Festival.

\section{The Samples}

The survey took place in Potchefstroom, where the Aardklop National Arts Festival is held annually. The Aardklop terrain is referred to by local residents as "Die Bult". Questionnaires were distributed accordingly among entrepreneurs and SMME owners in this area.

In total, 520 questionnaires were distributed (Table 1). There are currently approximately 70 permanent small businesses in this area and 450 stands at the Aardklop National Arts Festival. Fieldworkers distributed questionnaires and collected completed questionnaires during the course of the festival. Hence all businesses formed part of the survey, based on their willingness and availability to complete the questionnaire.

Table 1: Questionnaires distributed, completed and analysed.

\begin{tabular}{|l|c|c|c|c|c|c|}
\hline \multirow{2}{*}{} & \multicolumn{2}{|c|}{$\begin{array}{c}\text { A } \\
\text { Total } \\
\text { distributed }\end{array}$} & \multicolumn{2}{c|}{$\begin{array}{c}c \\
\text { B } \\
\text { Questionnaires received } \\
\text { Questionnaires } \\
\text { analysed }\end{array}$} \\
\cline { 2 - 7 } & Amount & \% & Amount & \% & Amount & \% \\
\hline $\begin{array}{l}\text { Temporary } \\
\text { Stands }\end{array}$ & 450 & $86.5 \%$ & 190 & $37 \%$ & 186 & $36 \%$ \\
\hline $\begin{array}{l}\text { Permanent Small } \\
\text { Businesses }\end{array}$ & 70 & $13,5 \%$ & 36 & $6,9 \%$ & 36 & $7 \%$ \\
\hline Total & $\mathbf{5 2 0}$ & $\mathbf{1 0 0 \%}$ & $\mathbf{2 2 6}$ & $\mathbf{4 3 , 5 \%}$ & $\mathbf{2 2 2}$ & $\mathbf{4 2 , 7 \%}$ \\
\hline
\end{tabular}

\section{The Method}

Microsoft Excel was used for data capturing and basic data analysis. Exploratory factor analysis was performed to validate the constructs by means of SPSS. Reliability tests were also performed and descriptive data were used, especially for the profile of entrepreneurs. 


\section{Results}

The results will be discussed in two sections: firstly, an overview of the profile of the entrepreneurs who attended the Aardklop National Arts Festival and, secondly, the results of the factor analysis (entrepreneurial success factors).

The results captured in Table 2 concerning entrepreneurs attending the Aardklop festival showed that the majority of the respondents were female and Afrikaans speaking and between the ages of 35 and 49 years. Most of these entrepreneurs are married and have either a degree or diploma. The average business profile of the entrepreneurs at the Aardklop National Arts Festival shows that they have more than $50 \%$ share in their business, which they have started on their own and operate mainly from their homes, situated in the North West and Gauteng provinces (See Table 2). The entrepreneurs view their role at the festival as delivering unique and quality products. In order to reach this objective, they have to market their products to make festival attendees aware of their new and unique products.

Table 2: Entrepreneurs’ profile: Aardklop National Arts Festival 2007

\begin{tabular}{|c|c|}
\hline Variable & Averages \\
\hline Gender & $67 \%$ Female \\
\hline Language & 72\% Afrikaans \\
\hline Age & $\begin{array}{l}41 \% \text { between } \\
35-49 \text { years }\end{array}$ \\
\hline Marital Status & 72\% Married \\
\hline Qualification & 50\% Diploma/degree \\
\hline Shares & $67 \%$ have more than $50 \%$ shares \\
\hline How business started & $87 \%$ started their business on their own \\
\hline Operate from & $60 \%$ operate their business from their home \\
\hline Province & $\begin{array}{l}\text { 36\% North West Province } \\
\text { 24\% Gauteng }\end{array}$ \\
\hline Reasons for attending Aardklop & $\begin{array}{l}\text { Marketing business } \\
\text { To expand business }\end{array}$ \\
\hline Role at Aardklop & $\begin{array}{l}\text { To deliver unique and quality products and } \\
\text { services } \\
\text { To do marketing for their business }\end{array}$ \\
\hline
\end{tabular}

The next section will deal with the attributes of entrepreneurs as indicated by the factor analysis.

The factor analysis identified six factors (Table 3). These factors were labelled as: organisational skills, resourcefulness, achievement, self-edification, explorative tendency and commitment. 
Table 3: Results of the factor analysis

\begin{tabular}{|c|c|c|c|c|c|c|}
\hline \multicolumn{7}{|c|}{ Pattern Matrix } \\
\hline & \multicolumn{6}{|c|}{ Factors } \\
\hline & \begin{tabular}{|c|} 
Organisational \\
Skills
\end{tabular} & Resourcefulness & Achievement & \begin{tabular}{|c|} 
Self- \\
edification
\end{tabular} & Explorative & Commitment \\
\hline $\begin{array}{l}\text { Management } \\
\text { skills }\end{array}$ & .479 & & & & & \\
\hline Calculated risks & .737 & & & & & \\
\hline Optimism & .314 & & & & & \\
\hline $\begin{array}{l}\text { Time } \\
\text { management }\end{array}$ & .622 & & & & & \\
\hline $\begin{array}{l}\text { Thought-through } \\
\text { plans }\end{array}$ & .578 & & & & & \\
\hline Teamwork & .757 & & & & & \\
\hline Ambition & & .597 & & & & \\
\hline Creativity & & .737 & & & & \\
\hline Dedication & & .799 & & & & \\
\hline Initiative & & .786 & & & & \\
\hline Innovation & & .858 & & & & \\
\hline Vision & & .332 & & & & \\
\hline Give best & & & .858 & & & \\
\hline Profit driven & & & & -.530 & & \\
\hline Knowledge & & & & -.381 & & \\
\hline Education & & & & -.720 & & \\
\hline $\begin{array}{l}\text { To always be } \\
\text { successful }\end{array}$ & & & & -.883 & & \\
\hline To always win & & & & -.817 & & \\
\hline Independence & & & & -.309 & & \\
\hline Leadership & & & & -.491 & & \\
\hline Optimism & & & & & .311 & \\
\hline Adventurousness & & & & & .497 & \\
\hline Hard work & & & & & & .375 \\
\hline Communication & & & & & & .530 \\
\hline Confidence & & & & & & .778 \\
\hline Opportunities & & & & & & .565 \\
\hline $\begin{array}{l}\text { Cronbach } \\
\text { Alphas }\end{array}$ & .798 & .847 & N/A & .838 & .446 & .780 \\
\hline
\end{tabular}


Table 4: Correlation Matrix

\begin{tabular}{|l|r|r|r|r|r|r|}
\hline \multicolumn{7}{|c|}{ Correlation Matrix } \\
\hline Factors & $\begin{array}{l}\text { Organisational } \\
\text { Skills }\end{array}$ & Resourcefulness & Achievement & $\begin{array}{l}\text { Self- } \\
\text { edification }\end{array}$ & Explorative & Commitment \\
\hline Organisational & 1.000 & .391 & .093 & -.462 & .041 & .339 \\
\hline Resourcefulness & .391 & 1.000 & .172 & -.417 & .090 & .357 \\
\hline Achievement & .093 & .172 & 1.000 & -.088 & .025 & -.010 \\
\hline Self-edification & -.462 & -.417 & -.088 & 1.000 & -.052 & -.377 \\
\hline Explorative & .041 & .090 & .025 & -.052 & 1.000 & .060 \\
\hline Commitment & .339 & .357 & -.010 & -.377 & .060 & 1.000 \\
\hline
\end{tabular}

Extraction Method: Principal Component Analysis.

Rotation Method: Oblimin with Kaiser Normalisation.

The Correlation Matrix as captured in Table 4 shows a low correlation between the various factors, which is an indication that the factors are well distinguished and defined.

Cronbach Alphas were determined (Table 3) to test the reliability of the identified factors, with the exception of factor 3, which consists of only one component. The Cronbach Alpha analyses showed very good correlations between the components within each factor. Factor 4, which is that of the entrepreneur as explorer, has however a lower Cronbach Alpha mean, and can thus be seen as an area that requires more statements (components).

Factor 1: Organisational Skills

The organisational skills included aspects such as management skills, calculated risks, time management, thought-through plans and team work. The importance of this factor is confirmed by Dias and McDermott (2006) and Brush (2008), who point out that entrepreneurs create and organise new firms and industries, while managing and encouraging workers with a minimum level of human capital (Dias \& McDermott, 2006:299; Brush, 2008:21). This factor had a mean value of 4.20 .

\section{Factor 2: Resourcefulness}

This factor had the second highest mean value (4.49) and includes aspects such as ambition, dedication, creativity, initiative, innovation, optimism and vision. According to Manz and Snyder (1983:68) and Hart (2008:149), in order for an individual to become a resourceful entrepreneur, attributes such as innovation and vision are extremely important (Manz \& Snyder, 1983; Hart, 2008).

\section{Factor 3: Achievement}

The entrepreneurs indicated that to always give of their best is of the utmost importance to them. This factor had the highest mean value (4.58). An analysis undertaken by Rauch and Frese (2007) found that evidence of the entrepreneurs' need to give of their best is portrayed in their need for achievement (Rauch \& Frese, 2007:353). 
Factor 4: Self-edification

Self-edification includes being profit driven, having knowledge, being educated, wanting to always be successful, to always win, having independence, and possessing leadership. Covey states that self-edification is a frame of mind and heart that constantly seeks personal benefit in all human actions (1989:207). Interesting is the fact that this factor had the lowest mean value of all six factors (3.92).

\section{Factor 5: Explorative tendency}

This factor determines to what extent optimism and adventure contribute to the entrepreneurs' need to explore. It confirms that entrepreneurs experience a need to explore new business ventures and to introduce new products. This factor had a mean value of 4.07.

\section{Factor 6: Commitment}

This factor had the third highest mean value (4.44). Hard work, communication, confidence and seeking/taking opportunities all contribute to and form part of the entrepreneurs' vision for their businesses. According to a previous survey, Kenyan and Ghanaian business owners stipulated that hard work and commitment are essential for entrepreneurial success in ultimately achieving their long-term vision (Hung, Benzing \& McGee, 2007:298).

The next section will deal with the findings and conclusions of this research.

\section{Discussion}

\section{Relationship between findings and literature}

The results of the factor analysis revealed six factors (attributes) of importance to entrepreneurs' success, namely organisational skills, resourcefulness, achievement, selfedification, explorative tendency and commitment. From the results of the literature review, it became clear that these findings support research by Rotefoss and Kolvereid (2005), who suggest that entrepreneurs are explorative and develop new products, methods and approaches. It also supports work by Saayman and Snyman (2005), who suggest that entrepreneurs require organisational skills. They are resourceful (Saayman \& Snyman, 2005) and self-edificatory (Homozi, 2004; Lapini, 2007) and committed (Homozi, 2004; Lapini, 2007). A similar set of attributes could not be found in the literature, which confirms that there does not seem to be one set of attributes for entrepreneurs in general, but rather a variety. The results, however, show that the combination of attributes and stress laid upon certain attributes seem to differ from sector to sector or industry to industry. The fact that no similar studies done at arts festivals were found also makes it difficult to draw comparisons.

Another interesting finding from this research, if one looks at the mean values of the different attributes, is that the three most-important attributes, namely achievement, resourcefulness and commitment, can be categorised as personal attributes. This implies that the essence of entrepreneurs at this festival is of a personal nature and that these characteristics cannot necessarily be taught or adopted. The attribute mostly associated with entrepreneurs, namely self-edification (being profit driven, having knowledge and education, etc.) scored the lowest mean value. This might be ascribed to lower expectations by the entrepreneurs of generating a 
high income at festivals. The results also support the work done by Spilling (1996) and Tyson et al. (2005), who indicate that a big event, in this case an arts festival, can trigger entrepreneurial activities.

\section{Limitations of the study}

The biggest limitation is the absence of similar research done at arts festivals in order to draw lessons from. This is especially relevant to the questionnaire development and comparison of results from other arts festivals or events.

\section{Implications for practitioners and policy makers}

The results could assist agencies concerned with assisting and expanding entrepreneurship in identifying people with these attributes. The attributes and profile could also be useful in terms of developing training programmes to teach the basic skills and to change people's mindset in terms of entrepreneurship. Even though the latter was not the purpose of this research, the research did indicate basic skills (organisational skills) that are required. The latter (see Table 3) include the ability to determine risks, the ability to do proper planning and to manage time. The research could also assist festival organisers in selecting entrepreneurs for this particular arts festival, since the research provides a profile as well as key attributes. The results also show that even though training is important, personal attributes seem to be the driving force behind these entrepreneurs. Therefore, the Aardklop organisers and agencies concerned with entrepreneurs cannot rely on skills or qualification alone as a benchmark for entrepreneurs.

\section{Directions for future research}

Similar research at other festivals would be invaluable to confirm or reject the view portrayed above. In the case of this research, most of the entrepreneurs are from a homogeneous group, namely Afrikaans-speaking, predominantly white, females, and one could probably expect a different set of attributes for other cultural groups or a different event. This should be pursued. Once again the research shows that too little has been done on this topic at arts festivals. Another aspect that should be refined is the questionnaire. This can be done by adding a few statements that could measure achievement more effectively.

\section{Conclusions}

Entrepreneurs and their businesses have always been a popular topic for research and enjoy attention from researchers all over the world. The aim of this article was to focus on the attributes of entrepreneurs at arts festivals, using the Aardklop National Arts Festival as a case study. This was the first time that this type of research was conducted at an arts festival in South Africa.

According to the 2006 South African Report from the Global Entrepreneurship Monitor (GEM), entrepreneurship on a micro-level is not showing any signs of growth, but on a macro-level, a positive entrepreneurial culture is starting to form (Maas \& Herrington, 2006:4). The latter is very important for the management of the Aardklop National Arts Festival, since entrepreneurial activities hold many economic benefits. Festivals are accepting 
their responsibility in growing entrepreneurs and this research could assist festival coordinators in developing strategies to achieve this.

The contribution of this research lies in the confirmation of the six main attributes, namely organisational skills, resourcefulness, achievement, self-edification, explorative and commitment, as the most important attributes of entrepreneurs at the Aardklop National Arts Festival, as well as the importance of these factors for entrepreneurial success.

\section{References}

Africa Policy Information Centre. 2002. Africa: Economic Report on Africa. [Online] Available from: http://www.africaaction.org/docs02/eca2002a.htm [Accessed: 2008-11-10]

Aitchison, C. \& Pritchard, A. 2007. Festivals and events: culture and identity in leisure, sport and tourism. Eastbourne: LSA.

Anwar, S.A. \& Sohail, M. S. 2004. Festival tourism in the United Arab Emirates: first-time versus repeat visitor perception. Journal of Travel Research, 10(2):161-170.

Austin, N.K. 2003. Entrepreneurship development and tourism in rural African communities. Journal of African Business, 4(1):87-101

Barnard, A.F. 1988. Omgewingsverkenning by ' $n$ geselekteerde groep kleinsakeondernemings in die PWVgebied. Unpublished MBA-thesis. Potchefstroom: PU for CHE.

Binns, T. \& Nel, E. 2002. Tourism as a local development strategy in South Africa. Geographical Journal, 168(3):235-247.

Brown, G. 2005. HM Treasury: Chancellor announcement. November, 15. [Online] Available from: http://www.nfte.co.uk [Accessed: 2007-03-27].

Brush, C.G. 2008. Pioneering strategies for entrepreneurial success. Business Horizons, 51(1):21-27.

Cleverdon, R.G. 2002. Tourism development in the SADC region: the opportunities and challenges. Development Southern Africa, 19(1):7-28.

Covey, S.R. 1989. The 7 habits of highly effective people. New York: Free Press.

Dahles, H. \& Bras, K. 1999. Tourism and small entrepreneurs: development, national policy and entrepreneurial culture: Indonesian cases. New York: Cognizant Communication Corporation.

Dias, J. \& McDermott, J. 2006. Institutions, education and development: the role of entrepreneurs. Journal of Development Economics, 80(2):299-328.

Elliot, R. \& Boshoff, C. 2007. The influence of the owner-manager of small tourism businesses on the success of internet marketing. South African Journal of Business Management, 38(3):15-27.

Haasje, K.P. 2006. South African micro entrepreneurs and resources to overcome entry barriers. Journal of Contemporary Management, (3):43-59.

Hart, D.M. 2008. The politics of entrepreneurial economic development policy of states in the U.S. Review of Policy Research, 25(2):149-168.

Hormozi, A.M. 2004. Becoming an entrepreneur: how to start a small business. International Journal of Management, 21(3):278-285. 
Hung, M.C., Benzing, C. \& McGee, C. 2007. Ghanaian and Kenyan entrepreneurs: a comparative analysis of their motivations, success characteristics and problems. Journal of Developmental Enterprises, 12(3):295-322.

Kimani, E. 2004. MTI-AITI Entrepreneurship: lecture 8: entrepreneurship; summary. [Online] Available from: http://ocw.mit.edu/NR/rdonlyres/SpecialPrograms/SP772Spring2005/BB5F17F9-6575-4FDO-BZAF51A440D5EF84/ [Accessed: 2007-03-27].

Kirsten, M. \& Rogerson, C.M. 2002. Tourism business linkages and small enterprise development in South Africa. Development Southern Africa, 19(1):29-59.

Kroon, J. 2002. 'n Strategie vir entrepreneurskapontwikkeling in Suid-Afrika. Tydskrif vir Geesteswetenskappe, 42(3):215-223.

Kruger, M., Saayman, M. \& Saayman, A. 2008. Die profiel en ekonomiese impak van Aardklop Nasionale Kunstefees. Potchefstroom: Institute for Tourism and Leisure Studies.

Lapini, A. 2007. 50 Characteristics of successful entrepreneurs. March, 24. [Online] Available from: http://www.independentonline.com/?c=1908a=23354 [Date of access: 4April 2007].

Longenecker, J.G., Moore, C.W. \& Petty, J.W. 2000. Small business management: an entrepreneurial emphasis. 11th ed. Chicago: South-Western College Publishing.

Longenecker, J.G., Moore, C.W. \& Petty, J.W. 2003. Small business management: an entrepreneurial emphasis. 12th ed. Chicago: South-Western College Publishing.

Maas, G. \& Herrington, M. 2006. Global Entrepreneurship Monitor: South African report. Cape Town: UCT Graduate School of Business.

Manz, C.C. \& Snyder, C.A. 1983. How resourceful entrepreneurs meet business challenges...and survive. Management Review, 72(10):68-73.

Marshall, A. 1920. Principles of Economics. [Online] Available from: http://www.econlib.org/library/Marshall/marP15.html\#Bk.IV,Ch.I [Accessed: 2008.11.10].

McKercher, B., Mei, W.S. \& Tse, T.S.M. 2006. Are short duration cultural festivals tourist attractions? Journal of Sustainable Tourism, 14(1):55-66.

Mitton, D.M. 1998. Entrepreneurskap na tersiêre opleiding. Unpublished MBA thesis. Vanderbijlpark: PU for CHE.

Muhanna, E. 2006. The contribution of sustainable tourism development in poverty alleviation of local communities in South Africa. Journal of Human Resources in Hospitality and Tourism, 6(1): 7-67.

National Arts Festival. 2007. National Arts Festival. [Online] Available from: http://en.wikipedia.org/wiki/National_Arts_Festival [Accessed: 2007-10-05].

Ndabeni, L. \& Rogerson, C.M. 2005. Entrepreneurship in rural tourism. Africa Insight, 35(4):130-140.

Olivier, E. 2002. Opportunities for Small, Medium and Micro-tourism enterprises in South Africa. Unpublished M.Com thesis. Potchefstroom: PU for CHE.

Rauch, A. \& Frese, M. 2007. Let's put the person back into entrepreneurship research: a meta-analysis on the relationship between business owners' personality traits, business creation, and success. European Journal of Work \& Organisational Psychology, 16(4): 353-385.

Rogerson, C.M. 2005. Unpacking tourism SMMEs in South Africa: structure, support needs and policy response. Development Southern Africa, 22(5):623-642. 
Rotefoss, B. \& Kolvereid, L. 2005. Aspiring, nascent and fledgling entrepreneurs: an investigation of the business start-up process. Entrepreneurship \& Regional Development, 17(2):109-117.

Saayman, M. \& Olivier, E. 2005. An analysis of tourism SMMEs in South Africa. South African Journal of Sport, Physical Education and Recreation, 27(1):133-142.

Saayman, M. \& Saayman, A. 2006. Does location of arts festivals matter? Regional Science, 85(4):569-584.

Saayman, M. \& Snyman, J.A. 2005. Entrepreneurship: tourism style. Potchefstroom: LeisureC.

Schumpeter, J.A. 1912. Theorie der Wirtschaftlichen Entwicklung. $1^{\text {st }}$ ed in English, The theory of economic development. Cambridge: Harvard University Press. .

Slabbert, E., Saayman, M., Saayman, A. \& Kruger, M. 2008(a). Profile and economic impact of visitors to Grahamstown National Arts Festival. Potchefstroom: Institute for Tourism and Leisure Studies.

Slabbert, E., Viviers, P., Saayman, M., Saayman, A. \& Dreyer, A. 2008(b). Die sosio-ekonomiese impak van besoekers aan ABSA KKNK te Oudtshoorn. Potchefstroom: Institute for Tourism and Leisure Studies.

Spilling, O.R. 1996. The entrepreneurial system: an entrepreneurship in the context of a mega-event. Journal of Business Research, (36):91-103

Starting your own business. 2005. Finance Week: Special section, 29(June):3.

Timmons, J.A. \& Spinelli, S. 2004. New venture creation: entrepreneurship in the $21^{\text {st }}$ century. New York: McGraw-Hill.

Trigg, P. 1995. Leisure and Tourism GNVQ: intermediate textbook. Oxford: Butterworth-Heinemann.

Tustin, D.H., Lighthelm, A.A., Martins, J.H. \& Van Wyk, H.J. 2005. Marketing research in practice. South Africa: Unisa Press.

Tyson, B., Hayle, C., Truly, D., Jordan, L.A. \& Thame, M. 2005. West Indies World Cup cricket: hallmark events as catalysts for community tourism development. Journal of Sport Tourism, 10(4):323-334.

Van der Merwe, L.H. 2008. The socio-economic impact of the KKNK in Oudtshoorn. Unpublished Master's thesis. Potchefstroom: North West University.

Van der Merwe, M. 1994. ' $n$ Entrepreneurskapsontwikkelingsmodel vir werkskepping as sosiale investering van ondernemings. Unpublished PhD thesis. Potchefstroom: PU for CHE.

Van der Westhuizen, T. 2003. Key success factors for developing and managing a guesthouse. Unpublished Master's thesis. Potchefstroom: PU for CHE. 